\title{
Board characteristics and cost of debt: Evidence from Indonesia
}

\author{
Stefany Stefany \\ Department of Accounting, Maranatha Christian University \\ Jl. Prof. drg. Surya Sumantri, M.P.H No. 65 Bandung \\ Stefanny131313@gmail.com \\ Joni Joni* \\ Department of Accounting, Maranatha Christian University \\ Jl. Prof. drg. Surya Sumantri, M.P.H No. 65 Bandung \\ joni@eco.maranatha.edu \\ *Penulis Korespondensi
}

Submitted: Feb 6, 2020; Reviewed: Feb 18, 2020; Accepted: Apr 24, 2020

\begin{abstract}
Corporate governance has been an important issue for investors, practitioners, and regulators. This is because board characteristic as central feature of corporate governance has a significant impact on the economy and the firm's operation. This study investigates the effect of board characteristics on cost of debt for the Indonesian listed companies for the period 2016-2017. The final sample of this study is 777 firm-year observations. We use multiple regressions for the main analysis and Generalized Method of Moments (GMM) to test for endogeneity. The results show that board size is negatively significantly associated with the cost of debt, yet female board and independent boards are not related to cost of debt. The results are still consistent after testing for endogeneity issue.
\end{abstract}

Keywords: board size; cost of debt; gender diversity; independent supervisory board

Abstrak: Tata kelola merupakan isu yang penting bagi investor, praktisi, dan pembuat regulasi. Hal ini yang menjadikan karakterisktik dewan, yang merupakan fitur utama dalam sistem tata kelola, memiliki dampak yang signifikan terhadap ekonomi dan operasi perusahaan. Studi ini menginvestigasi dampak karakteristik dewan terhadap biaya hutang (cost of debt) pada perusahaanperusahaan yang listing di Bursa Efek Indonesia periode 2016-2017. Sampel akhir pada studi ini adalah 777 observasi. Kami menggunakan regresi untuk melakukan analisis utama dan Generalized Method of Moments (GMM) untuk menguji isu endogenitas (endogeneity). Hasilnya menunjukkan bahwa ukuran dewan berasosiasi secara negatif dan signifikan terhadap biaya hutang, tetapi jumlah dewan wanita dan dewan independen tidak berhubungan dengan biaya hutang. Hasil pengujian ini tetap konsisten setelah dilakukan pengujian isu endogenitas.

Kata Kunci: biaya hutang; dewan komisaris independen; keberagaman gender; ukuran dewan

\section{INTRODUCTION}

In this paper, we explore the association between board characteristics and cost of debt in Indonesia listing companies during 2016-2017. The board mechanism is one of the crucial pillars in corporate governance that has the role in overseeing, advising top management, and protecting shareholder's interests (Johl, Kaur, \& Cooper, 2015). The presence of the board can improve the value of the firm in 
the long run and lower cost of having credits. Some characteristics of board are negatively associated with cost of debt. Florackis (2008) argues that companies with large board size can improve company's effectiveness. It argues that firms with larger board size have more external information that help them to obtain funds with lower interest costs (Lehn, Patro, \& Zhao, 2009). Several empirical studies show that board size affects the cost of debt. For instance, Pandey, Biswas, Ali, \& Mansi (2019) find board size is negatively associated with the cost of debt, meaning that more members of the board resulting lower the cost of debt. Similarly, Shuto \& Kitagawa (2011) show that firms with large board size reduces cost of debt. In addition to board characteristics, the presence of independent boards as one of the features of corporate governance serves to balance the process of decision making, particularly in protecting minority shareholders and other stakeholders (Juniarti \& Sentosa, 2010). They are expected to provide better supervision and to lower the cost of debt (Marrakchi Chtourou, Bedard, \& Courteau, 2001). Usman, Farooq, Zhang, Makki, \& Khan (2019), for example, find that independent board of commissioners lower cost of debt in China. Another board characteristic is the proportion of women who serve as board members. Many countries across the world promote the role and the effectiveness of female directors as a central issue in corporate governance (Sila, Gonzalez, \& Hagendorff, 2016). For instance, the Prime Minister of Japan has set a goal to initiate "Shining women" or known as "Womenomics" (Abe, 2018). The Japanese State Government expects that the number of women in top manager positions will increase $30 \%$ by 2020 (Gelb, 2011). Grant Thornton International (2018) reports that the percentage of the companies in the world that have better performance after employing at least one woman as a senior manager has increased from $66 \%$ to $75 \%$. Städtler (2016) shows a negative relation between gender equality in the board of directors and the cost of debt in one-tier board system. ${ }^{1}$ Similarly, Usman et al. (2019) argue that female directors eliminate information asymmetry between management stakeholders, management's opportunistic behavior, and the probability of default on loans and cost of debt based on creditor perceptions. Further, Usman et al. (2019) find that creditors charge 4 percent less to debitors who have at least one woman as board member in single board context.

Our study is different from prior literature in several ways. First, our study uses Indonesian context to examine the board characteristics and cost of debt. It is still not clear whether the presence of corporate governance system works well in emerging countries, such as Indonesia where weak law enforcement can reduce the application of corporate governance system. Our study shows evidence which supports the implementation of corporate governance in emerging countries. Second, we use GMM (Generalized Method of Moments) to address endogeneity problem. The issue of corporate governance research is the possibility of endogenously determined. Consequently, the observed relationship between board characteristics and cost of debt may be spurious. By using GMM, the result of our study is more reliable than prior studies to justify the results.

As stated earlier, the objective of this study is to identify whether board characteristics (size, independence, and gender) affect the cost of debt. The results of this paper are expected to contribute to the literature, especially in the relation between board characteristics and the cost of debt in the Indonesian dual board context. In addition, the findings contribute to the policy makers and practitioners by providing additional information to develop governance practices and the importance of governance in reducing the cost of debt.

Agency theory explains the relationship between one party, called agent (management who works on behalf of principal) and principal (owner) as another party (Jensen \& Meckling, 1976). This relationship will cause a conflict which called as agency conflict. This theory assumes that management can expand their own welfare by reducing agency costs arising from monitoring and administering contracts (Young, Peng, Ahlstrom, Bruton, \& Jiang, 2008). Based on this assumption, agency theory argues that the different objectives between principal (shareholders) and agent (management) can cause conflict because managers tend to pursue their personal interests instead of maximizing the welfare of shareholders. This is called agency conflict type 1. However, in emerging market (such as Indonesia) where ownership structure is concentrated, the conflict is between majority and minority shareholders often called as agency conflict type 2 (Young et al., 2008).

\footnotetext{
${ }^{1}$ Board of director in one-tier board is responsible for monitoring and supervising functions. In the paper, we use board of director who is responsible for day-to-day operation and board of commissioner who is responsible for monitoring and supervising board of director in the two-tier board context.
} 
Corporate governance system is a tool to minimize this agency conflict (either type 1 or type 2) through board's expertise and their monitoring and supervision functions. The presence of the board in the governance mechanism is important to improve monitoring and supervision functions of corporate management. An effective board monitoring can reduce fund misallocation, thereby increasing shareholder value. For instance, prior studies find that the size of the board affects their monitoring function. As a result, firms with larger size of board member will have more resources or will have more credit access (e.g. Lorca, Sánchez-Ballesta, \& García-Meca, 2011). In addition, Adams \& Ferreira (2009) show that female boards perform better monitoring functions. Further, the presence of independent directors can also increase transparency and monitoring functions (Terjesen, Couto, \& Francisco, 2016). Thus, board characteristics (size, independent, and gender) can reduce agency conflict by increasing their monitoring and supervising functions.

Further, Resource Dependency Theory (Pfeffer \& Salancik, 1978) and Stakeholder Theory (Freeman, 2010) argue that the presence of good governance can have a positive influence on firm value. Resource Dependency Theory explains that the board of commissioners and the board of directors could protect companies from business uncertainties. Individually, members of the board of directors and the board of commissioners with different backgrounds will bring important resources for the company (Siciliano, 1996). Additionally, Stakeholder Theory describes that companies operate not only for their own interests, but for the benefits of stakeholders (Handoko \& Malang, 2014). Thus, the existence of a company is strongly affected by stakeholder supports. Freeman (2010) assert that companies should maintain its relationship with stakeholders by accommodating their interests, especially stakeholders who have power to bring the resources used from outside, such as professional employees, market for the company's products and others. The implementation of good governance system can provide benefits to all stakeholders so that it is expected to enhance the value of the company. This will reduce risks and increase trust in the perspective of creditors, consequently creditors provide lower debt costs to the company (Wibowo \& Nugrahanti, 2013). Under both theories, board characteristics (size, independent, and gender) can improve firm value as reflected in lower cost of debt.

In line with the theories, empirical studies show that board size is negatively related to cost of debt (Pandey et al., 2019). Then, Usman et al. (2019) show a negative association between independent board and cost of debt. When company has independent board of commissioners who have responsible for monitoring corporate management, the integrity of the financial statement and disclosures are increasing. This will support creditors to reduce cost of debt of the company because the risk and the uncertainty of the company are low. Similarly, the presence of female board might reduce company's risk and lower cost of debt (Usman et al., 2019). This is because female board members are more independent and more selective in taking risks (Abbott, Parker, \& Presley, 2012). Most of these studies using developed countries and one-tier board system. As far as we understand, limited studies on the association between board characteristics and cost of debt in emerging markets with two-tier board system.

Based on the theoretical frameworks and prior studies, the following hypotheses are proposed. H1a: The board size is associated with the cost of debt.

$\mathrm{H} 1 \mathrm{~b}$ : The independent board of commissioner is associated with the cost of debt.

H1c: The percentage of female board is associated with the cost of debt.

\section{METHOD}

The sample of this paper is all listed firms on the Indonesia Stock Exchange (IDX) for the period 2016-2017. We exclude financial services companies in our sample as they are under different regulations. All corporate governance data is manually collected, while financial data is obtained from Data stream. After deleting observation with missing data, our final sample is 777 firm-year observations. We winsorise the continuous variables at the 2nd and 98th percentiles, except for the dummy variables. The detail of sample selection is reported in Table 1. 
Table 1. Description of the sample

\begin{tabular}{lccc}
\hline \multicolumn{1}{c}{ Calendar year } & 2016 & 2017 & Total \\
\hline Number of listed companies & 539 & 555 & 1.094 \\
$\begin{array}{l}\text { Number of firms from financial } \\
\text { industry }\end{array}$ & 105 & 121 & 226 \\
$\begin{array}{l}\text { Number of firms with missing data } \\
\text { Number of firms in the sample }\end{array}$ & 59 & 32 & 91 \\
\hline
\end{tabular}

Source: Processed research data

To test the effect of board characteristics and cost of debt, we estimate the following baseline empirical model.

$$
\begin{gathered}
\mathrm{COD}=\mathrm{a}+\beta 1 \mathrm{LNBOD}+\beta 2 \mathrm{INDSB}+\beta 3 \text { FEMPCT }+\beta 4 \mathrm{LNAGE}+\beta 5 \mathrm{INCOV}+\beta 6 \\
\text { GROWTH_SALES }+\beta 7 \mathrm{LNSL}+\beta 8 \mathrm{LEV}+\mathrm{e}
\end{gathered}
$$

The dependent variable is cost of debt (COD) and independent variable is board characteristics measured by three variables: board size (LNBOD), the independent board of commissioners (INDSB), and the percentage of women in the board (FEMPCT). To test the effect of board characteristics on the cost of debt, we control firm age (LNAGE), interest coverage (INCOV), growth sales (GROWTH_SALES), firm size (LNSL), and leverage (LEV). All control variables are selected because they are consistent with prior research. Firm age indicates how long the company is operating (Utami \& Prastiti, 2011). Age of the company is expected to have a negative effect on cost of debt. Companies which have stay longer in IDX should be able to maintain its existence and demonstrate its competitive ability (Isditanadevi \& Puspaningsih, 2014). In addition, interest coverage is also expected to be negative. According to Bliss \& Gul (2012), companies with higher interest coverage will have better firm value as they are capable to pay interest expenses and profitable. Company size and growth are expected to have a negative effect on the cost of debt (Soesetio, 2008). We also expect that cost of debt is positively associated with leverage (Jung, Herbohn, \& Clarkson, 2018). Variable definitions are reported in Table 2.

\begin{tabular}{|c|c|}
\hline Variable & Definition \\
\hline COD & $\begin{array}{l}\text { the cost of debt measured by interest expense divided by average total debt } \\
\text { (Fama \& French, 1997; Fu, Kraft, \& Zhang, 2012) }\end{array}$ \\
\hline LNBOD & $\begin{array}{l}\text { the natural log of number of directors on the board (Fama \& French, 1997; Fu } \\
\text { et al., 2012) }\end{array}$ \\
\hline INDSB & $\begin{array}{l}\text { the number of independent directors divided by board size (Fama \& French, } \\
\text { 1997; Fu et al., 2012) }\end{array}$ \\
\hline FEMPCT & $\begin{array}{l}\text { the percentage of number of women in the board divided by board size (Fama } \\
\& \text { French, 1997; Fu et al., 2012) }\end{array}$ \\
\hline \multicolumn{2}{|l|}{ Control variables } \\
\hline LNAGE & $\begin{array}{l}\text { the current year - the year when company first listing on the Indonesia Stock } \\
\text { Exchange (Bliss \& Gul, 2012) }\end{array}$ \\
\hline INCOV & the earning interest before tax divided by interest expense (Bliss \& Gul, 2012) \\
\hline LNSL & the natural log of number of total sales (Terjesen et al., 2016) \\
\hline GROWTH_SALES & (Sales year $\mathrm{t}$ - sales year $\mathrm{t}-1)$ divided by sales year $\mathrm{t}-1$ (Bliss \& Gul, 2012) \\
\hline LEV $\quad-$ & $\begin{array}{l}\text { The firm total liabilities divided by total assets (Fama \& French, 1997; Fu et } \\
\text { al., 2012) }\end{array}$ \\
\hline
\end{tabular}

Table 2. Definition of variables

Source: Literature reviews 


\section{RESULTS AND DISCUSSIONS}

Table 3 reports descriptive statistics for all variables in the models. It reports mean, minimum and maximum values, and deviation standards. The mean of COD as a dependent variable is 0.037 with a range of 0 to 0.35 . These values are consistent with prior studies (e.g. Pandey et al., 2019). In line with previous studies (e.g. Pandey et al., 2019), the means for independent variables (LNBOD; INDSB; and FEMPCT) are 2.099; 0.396; and 0.128, respectively. These statistical data show that the presence of independent commissioner boards and female boards are still nominal. Most companies do not really value the presence of independent commissioner boards and female boards in applying good corporate governance system. They have independent commissioners and female boards to meet the minimum requirement from the government.

Table 3. Descriptive statistics

\begin{tabular}{lccccc}
\hline \multicolumn{1}{c}{ Variable } & Observation & Minimum & Maximum & Mean & Std. Deviation \\
\hline COD & 777 & 0 & 0.355 & 0.037 & 0.031 \\
LNBOD & 777 & 1.386 & 3.135 & 2.099 & 0.353 \\
INDSB & 777 & 0 & 1 & 0.396 & 0.120 \\
FEMPCT & 777 & 0 & 0.6 & 0.128 & 0.124 \\
LNAGE & 777 & 0 & 3.638 & 2.505 & 0.841 \\
INCOV & 777 & -131.75 & 459.012 & 19.460 & 82.251 \\
GROWTH_SALES & 777 & -16.945 & 131.133 & 0.605 & 5.752 \\
LNSL & 777 & 18.411 & 32.959 & 27.608 & 2.268 \\
LEV & 777 & -1.027 & 3.39477 & 0.462 & 0.717 \\
\hline
\end{tabular}

Notes: The table presents the summary statistics of the main variables. The sample includes 777 firmyear observations for the period 2016-2017. All variables are based on calendar year. Variable definitions: COD is the Cost of Debt that measured by interest expense divided by average total debt. LNBOD is the natural log of number of directors on the board. INDSB is the number of independent directors divided by board size. FEMPCT is the percentage of number of women in the board divided by board size. LNAGE is the current year - the year when company first listing on the Indonesia Stock Exchange. INCOV is the earning interest before tax divided by interest expense. GROWTH _ SALES is (Sales year $\mathrm{t}$ - sales year $\mathrm{t}-1$ ) divided by sales year $\mathrm{t}-1$. LNSL is the natural logarithm of total sales. LEV is total long-term debt divided by the total assets.

Source: Processed research data

Table 4 shows the correlation test using Pearson product of moments. The biggest correlation occurs between LNBOD and LNSL with a value of 0.553 which means that the relationship between LNBOD and LNSL is quite strong and in the same direction (the higher the LNBOD, the higher the LNSL). The correlation between INCOV and COD is 0.244 , which means that the relationship between INCOV and COD is weak but certain and in the opposite direction (the higher the INCOV, the lower the COD). The correlation between LEV and COD is 0.204, which means that the relationship is very low and in the same direction (the higher the LEV, the lower the COD).

Table 4. Correlation matrix

\begin{tabular}{|c|c|c|c|c|c|c|c|c|c|}
\hline & COD & LNBOD & INDSB & FEMPCT & LNAGE & INCOV & $\begin{array}{l}\text { GROWTH } \\
\text { _SALES }\end{array}$ & LNSL & LEV \\
\hline COD & 1.000 & & & & & & & & \\
\hline LNBOD & $-0.146^{*}$ & 1.000 & & & & & & & \\
\hline INDSB & $0.064 * * *$ & $-0.063 *$ & 1.000 & & & & & & \\
\hline FEMPCT & $0.017 * *$ & $-0.150 *$ & $0.062 * * *$ & 1.000 & & & & & \\
\hline LNAGE & $-0.156^{*}$ & $0.083 * * *$ & $-0.016^{*}$ & $-0.141 *$ & 1.000 & & & & \\
\hline INCOV & $-0.244^{*}$ & $0.145 * * *$ & $-0.042^{*}$ & $-0.055^{*}$ & $-0.014^{*}$ & 1.000 & & & \\
\hline $\begin{array}{l}\text { GROWTH } \\
\text { _SALES }\end{array}$ & $-0.010^{*}$ & $-0.086^{*}$ & $-0.100^{*}$ & $-0.036^{*}$ & $-0.047^{*}$ & $-0.054^{*}$ & 1.000 & & \\
\hline LNSL & $-0.042^{*}$ & 0.553 & $-0.023^{*}$ & $-0.099 *$ & $0.130 * * *$ & $0.129 * * *$ & $-0.079 *$ & 1.000 & \\
\hline LEV & 0.204 & $0.083 * * *$ & $0.061 * * *$ & $-0.024 *$ & $-0.038^{*}$ & $-0.072^{*}$ & $-0.008^{*}$ & $0.133 * * *$ & 1.000 \\
\hline
\end{tabular}


Notes: The table reports the pairwise Pearson correlation matrix for the full sample (777 firm-year observations). Please see Table 2 for definitions of variables. *, **, *** indicate two-sided significance at the $1 \%, 5 \%$, and $10 \%$ levels, respectively.

Source: Processed research data

Table 5 provides the regression result on the association between board characteristics and cost of debt. Models I in Table 5 shows that board size has a relationship with debt costs at the one percent level (coefficient $=-0.013 ; \mathrm{t}=-3.67$ ). This result is consistent with hypothesis 1a. Large board (LNBOD) will benefit the company because they have wider network that will link company with external parties and improve firm value. This will increase the creditor's confidence to provide lower debt costs. Model II in Table 5 shows that Independent commissioners do not have effect on debt costs (coefficient $=0.008 ; \mathrm{t}=0.94)$. Hypothesis $1 \mathrm{~b}$ which states that 'independent commissioners have an effect on debt costs' is not supported. This is consistent with Stepanova \& Kopyrina (2019) in the context of BRIC countries (Brazil, Rusia, India, and China). The possible reason for this result is because the presence of an independent commissioner (INDSB) is simply to comply with government's regulations, without considering the effectiveness of independent boards and the complexity of a company. Model III in Table 5 reports that the percentage of women in board members (FEMPCT) does not have a significant relationship with cost of debt (coefficient $=-0.009 ; \mathrm{t}$ $=-1.03$ ). This result indicates that hypothesis $1 \mathrm{c}$ is not supported. It is possible due to the nominal role of female board in Indonesia. The presence of female boards is simply because of the pressure of social activists who encourage companies to have female on their board composition. It is a form of appreciation for women's emancipation and this leads to less experienced female boards in a company. As a result, the company does not properly consider the qualifications of female placed on the board. In our sample for instance, there are 280 firm-year observations out of 777 that do not have women on their board. Thus, the number of women on the board is not significant andthey are less competent.

Table 5. Board characteristics and cost of debt - OLS regression

\begin{tabular}{lccc}
\hline \multicolumn{1}{c}{ Variable } & Model I & Model II & Model III \\
\hline LNBOD & $-0.013^{* * *}$ & $-0.013^{* * *}$ & $-0.014^{* * *}$ \\
& $(-3.67)$ & $(-3.61)$ & $(-3.77)$ \\
\hline INDSB & & 0.008 & \\
& & $(0.94)$ & -0.009 \\
\hline FEMPCT & & & $(-1.03)$ \\
\hline LNAGE & $-0.005^{* * *}$ & $-0.005^{* * *}$ & $-0.006^{* * *}$ \\
& $(-4.16)$ & $(-4.15)$ & $(-4.27)$ \\
\hline INCOV & $-0.000^{* * *}$ & $-0.000^{* * *}$ & $-0.000^{* * *}$ \\
& $(-6.40)$ & $(-6.37)$ & $(-6.45)$ \\
\hline GROWTH- & -0.000 & -0.000 & -0.000 \\
SALES & $(-1.11)$ & $(-1.01)$ & $(-1.18)$ \\
\hline LNSL & 0.001 & 0.001 & 0.001 \\
& $(1.61)$ & $(1.60)$ & $(1.61)$ \\
\hline LEV & $0.008^{* * *}$ & $0.008^{* * *}$ & $0.008^{* * *}$ \\
& $(5.09)$ & $(5.02)$ & $(5.07)$ \\
\hline INTERCEPT & $0.052^{* * *}$ & $0.049^{* * *}$ & $0.055^{* * *}$ \\
& $(03.93)$ & $(3.52)$ & $(4.06)$ \\
\hline Year and Industry & Included & Included & Included \\
$\mathrm{N}$ & 777 & 777 & 777 \\
Prob F-Stat & 0.000 & 0.000 & 0.000 \\
$\mathrm{R}^{2}$ & 0.142 & 0.143 & 0.143 \\
Adj-R & 0.131 & 0.131 & 0.131 \\
Average VIF & 1.49 & 1.49 & 1.51 \\
\hline Not & 0.5 &
\end{tabular}

Notes: The table reports OLS coefficient estimates and dummy variables are included in the regression to control for year and industry differences. However, the results are not provided due to 
space constraints. All definitions of variables are listed in Table 2. *,**,*** indicate two-sided significance at the $1 \%, 5 \%$, and $10 \%$ levels, respectively.

Source: Processed research data

Overall, we find that firms with larger board size as one of board characteristics can minimize cost of debt. It means that the presence of boards is effective to obtain more external resources, such as debt with low interest rate. The boards use their external networks and professional competencies to affect the credit decision. Consequently, the creditors have a great confident to provide an easy credit access with lower interest rate for the company with more board members. In a similar vein, agency theory argues that good corporate governance is a vehicle to reduce agency conflict between agent (management) and principal (shareholders). Firms with more board members will have better monitoring function and capability to run the business. As a result, it will reduce the agency conflict and help company to get credit access with low interest rate.

However, other board characteristics (independent board commissioners and female boards) are not associated with cost of debt. As mentioned earlier, it is possible that the role of independent commissioner and female boards are not significant in the context of emerging countries, such as Indonesia. Many listed companies do not really care about the roles of independent boards. They just comply with the minimum requirements from the government. Also, it is quite similar with the presence of female as board members in Indonesia. It is possible that company recruits female boards due to social activist's pressure, instead of their expertise.

Table 6. Board characteristics and cost of debt-GMM

\begin{tabular}{lccc}
\hline \multicolumn{1}{c}{ Variable } & Model I & Model II & Model III \\
\hline LNBOD & $-0.014 * * *$ & $-0.013^{* * *}$ & $-0.014^{* * *}$ \\
& $(-3.96)$ & $(-3.65)$ & $(-3.72)$ \\
\hline INDSB & & 0.008 & \\
& & $(0.94)$ & -0.007 \\
& & & $(-0.85)$ \\
\hline FEMPCT & & $-0.006 * * *$ \\
& $-0.005^{* * *}$ & $-0.005^{* * *}$ & $(-3.80)$ \\
\hline LNAGE & $(-3.49)$ & $(-3.62)$ & $-0.000^{* * *}$ \\
& $-0.000^{* * *}$ & $-0.000^{* * *}$ & $(-10.10)$ \\
\hline INCOV & $(-10.50)$ & $(-10.17)$ & -0.000 \\
& -0.000 & -0.000 & $(-1.02)$ \\
\hline GROWTH- & $(-0.71)$ & $(-0.88)$ & 0.001 \\
SALES & 0.001 & 0.001 & $(1.56)$ \\
\hline LNSL & $(1.44)$ & $(1.56)$ & $0.008 * * *$ \\
& $0.008^{* * *}$ & $0.008^{* * *}$ & $(5.26)$ \\
\hline LEV & $(5.38)$ & $(5.20)$ &
\end{tabular}

Notes: The table reports GMM coefficient estimates and dummy variables are included in the regression to control for year and industry differences. However, the results are not provided due to space constraints. All definitions of variables are listed in Table 2. *, **, *** indicate two-sided significance at the $1 \%, 5 \%$, and $10 \%$ levels, respectively.

Source: Processed research data

Table 6 reports the sensitivity test to address endogeneity problem. It might possible that board characteristics affect cost of debt or vice versa. We use the General Method of Moment (GMM) to address this issue. Additionally, the GMM method is a useful tool when heteroscedasticity is presence. The condition of heteroscedasticity is not biased in the estimation model, meaning that even though population data shows a pattern of heteroscedasticity. After conducting GMM, the results of the three models are remaining similar. 


\section{CONCLUSIONS AND SUGGESTIONS}

Agency, Resources Dependency, and Stakeholder Theories suggest that corporate governance mechanism is an effective tool to reduce conflicts between principal and agent, to benefit stakeholders, and to adjust with changing external environment. The effectiveness of the board is one of the keys to implement good corporate governance. When board members conduct monitoring and supervising functions properly, it will increase firm's value and lower cost of capital. In the perspective of investors and creditors, firm with better monitoring will gain more trust compared to firms with poor monitoring. In addition, board's expertise and experiences can be a vehicle to add more value for the company as suggested by resource dependency theory. Board members will bring more external networks into the company. Consequently, the presence of board member will help company to obtain credit access with low interest rate.

This paper examines the association between characteristics of the boards (size, independence, and female) and cost of debt in Indonesia where the law enforcement is low. Based on 777 firm-year observation, it is found that board size is negatively significantly associated with the cost of debt. This concludes that the presence of board members is an effective way to reduce agency conflicts between agent and principal. Also, they use their networks, expertise, and experiences to bring resources for the company, especially in helping to get credit access with low interest rate. However, independent board of commissioners and female boards are not associated with the cost of debt. This is possibly because the presence of an independent board commissioner and female boards are only to fulfill government's requirements or social pressure. These results are also consistent after dealing with endogeneity problem by using GMM. However, the results of this study must be interpreted under several limitations. Firstly, we exclude financial industry from our sample because they are under different regulations. Future research could address the same issue for financial services companies. Secondly, the estimation of this model using quantitative method without any qualitative confirmation. Qualitative or mixed method to explore the effectiveness of board independence and the presence of female boards is needed for future research.

\section{REFERENCES}

Abbott, L.J., Parker, S., \& Presley, T.J. (2012). Female board presence and the likelihood of financial restatement. Accounting Horizons, 26(4), 607-629

Abe, S. (2018, 20 September). Why Japan's Women Problem is so Hard to Fix. Accessed from https://www.bloomberg.com/news/videos/2018-09-19/why-japan-s-women-problem-is-sohard-to-fix-video

Adams, R.B. \& Ferreira, D. (2009). Women in the boardroom and their impact on governance and performance. Journal of Financial Economics, 94(2), 291-309

Bliss, M.A. \& Gul, F.A. (2012). Political connection and cost of debt: Some Malaysian evidence. Journal of Banking \& Finance, 36(5), 1520-1527

Fama, E.F. \& French, K.R. (1997). Industry costs of equity. Journal of Financial Economics, 43(2), 153-193

Florackis, C. (2008). Agency costs and corporate governance mechanisms: Evidence for UK firms. International Journal of Managerial Finance

Freeman, R.E. (2010). Strategic Management: A Stakeholder Approach: Cambridge University Press

$\mathrm{Fu}, \mathrm{R}$., Kraft, A., \& Zhang, H. (2012). Financial reporting frequency, information asymmetry, and the cost of equity. Journal of accounting and economics, 54(2), 132-149

Gelb, J. (2011). Gender Equity in Japan and the United States. Accessed from https://ecpr.eu/Filestore/PaperProposal/2f952b8e63b4-4a1c-85bc-9601d7524fda.pdf

Grant Thornton International (2018). More businesses have women in senior leadership roles globally. Accessed from https://www.grantthornton.co.uk/news-centre/women-in-business-report-2018/

Handoko, Y. \& Malang, D.S.A. (2014). Implementasi social and environmental disclosure dalam perspektif teoritis. Jurnal JIBEKA, 8(2) 
Isditanadevi, N. \& Puspaningsih, A. (2014). Pengaruh ukuran perusahaan, struktur modal, profitabilitas, dan umur listing terhadap kualitas implementasi good corporate governance. Jurnal Bisnis dan Ekonomi, 5(2), 174-182

Jensen, M.C. \& Meckling, W.H. (1976). Theory of the firm: Managerial behavior, agency costs and ownership structure. Journal of Financial Economics, 3(4), 305-360

Johl, S.K., Kaur, S., \& Cooper, B.J. (2015). Board characteristics and firm performance: Evidence from Malaysian public listed firms. Journal of Economics, Business and Management, 3(2), 239-243

Jung, J., Herbohn, K., \& Clarkson, P. (2018). Carbon risk, carbon risk awareness, and the cost of debt financing. Journal of Business Ethics, 150(4), 1151-1171

Juniarti, J. \& Sentosa, A.A. (2010). Pengaruh good corporate governance dan voluntary disclosure terhadap biaya hutang (costs of debt). Jurnal Akuntansi dan Keuangan, 11(2), 88-100

Lehn, K.M., Patro, S., \& Zhao, M. (2009). Determinants of the size and composition of US corporate boards: 1935-2000. Financial Management, 38(4), 747-780

Lorca, C., Sánchez-Ballesta, J.P., \& García-Meca, E. (2011). Board effectiveness and cost of debt. Journal of Business Ethics, 100(4), 613-631

Marrakchi Chtourou, S., Bedard, J., \& Courteau, L. (2001). Corporate governance and earnings management. Corporate Governance and Earnings Management (April 21, 2001)

Pandey, R., Biswas, P.K., Ali, M.J., \& Mansi, M. (2019). Female directors on the board and cost of debt: evidence from Australia. Accounting \& Finance

Pfeffer, J. \& Salancik, G. (1978). The External Control of Organizations: A Resource Dependence Perspective. University of Illinois at Urbana-Champaign's Academy for Entrepreneurial Leadership Historical Research Reference in Entrepreneurship. Available at SSRN: https://ssrn.com/abstract=1496213

Shuto, A. \& Kitagawa, N. (2011). The effect of managerial ownership on the cost of debt: Evidence from Japan. Journal of Accounting, Auditing, \& Finance, 26(3), 590-620

Siciliano, J.I. (1996). The relationship of board member diversity to organizational performance. Journal of Business Ethics, 15(12), 1313-1320

Sila, V., Gonzalez, A., \& Hagendorff, J. (2016). Women on board: Does boardroom gender diversity affect firm risk? Journal of Corporate Finance, 36, 26-53

Soesetio, Y. (2008). Kepemilikan manajerial dan institusional, kebijakan dividen, ukuran perusahaan, struktur aktiva, dan profitabilitas terhadap kebijakan hutang. Jurnal Keuangan dan Perbankan, 12(3), 384-398

Städtler, L. (2016). The Effect of Gender Diversification in the Board on a Firm's Cost of Capital. Thesis. Uppsala University, Disciplinary Domain of Humanities and Social Sciences, Faculty of Social Sciences, Department of Business Studies

Stepanova, A. \& Kopyrina, O. (2019). The influence of ownership structure and board independence on the cost of debt in BRIC countries. Higher School of Economics Research Paper No. WP $B R P, 74$

Terjesen, S., Couto, E.B., \& Francisco, P.M. (2016). Does the presence of independent and female directors impact firm performance? A multi-country study of board diversity. Journal of Management \& Governance, 20(3), 447-483

Usman, M., Farooq, M.U., Zhang, J., Makki, M.A.M., \& Khan, M.K. (2019). Female directors and the cost of debt: does gender diversity in the boardroom matter to lenders? Managerial Auditing Journal, 34(4), 374-392

Utami, S. \& Prastiti, S.D. (2011). Pengaruh karakteristik perusahaan terhadap social disclosure. Jurnal Ekonomi Bisnis, 16(1), 63-69

Wibowo, P.F. \& Nugrahanti, Y.W. (2013). Mekanisme corporate governance terhadap biaya hutang. Jurnal Analisis Bisnis Ekonomi, 11(1), 93-105

Young, M.N., Peng, M.W., Ahlstrom, D., Bruton, G.D., \& Jiang, Y. (2008). Corporate governance in emerging economies: A review of the principal-principal perspective. Journal of Management Studies, 45(1), 196-220 
Jurnal Manajemen Maranatha — Vol. 19 Nomor 2, Mei (2020) 